\title{
Uptake of Leucine and Tyrosine and Their Intracellular Pools in Chlorella fusca var. vacuolata
}

\author{
By L. RICHARDS* AND C. F. THURSTON \\ Department of Microbiology, Queen Elizabeth College, Campden Hill Road, \\ London $W 87 A H$
}

(Received 26 October 1979)

Chlorella fusca var. vacuolata has high affinity active transport systems for the amino acids $\mathrm{L}-$-leucine and L-tyrosine. Leucine at $0.2 \mu \mathrm{M}$ was concentrated at least 222 -fold and tyrosine 920 -fold. Neither uptake process was inhibited by high concentrations of serine, threonine or phenylalanine. The concentration giving half-maximum rate of uptake was $2.5 \mu \mathrm{M}$ for leucine with a smaller value for tyrosine. The maximum uptake rate for leucine was 10 amol cell $^{-1} \mathrm{~min}^{-1}$. Uptake of leucine and tyrosine was not inhibited by $0.2 \mathrm{~mm}-2,4$-dinitrophenol, which completely inhibited the incorporation of radioactive leucine and tyrosine into protein. Intracellular radioactive leucine did not exchange with an excess of unlabelled leucine added to the medium, except during nitrogen starvation, and only partial exchange occurred with tyrosine. The apparent overall pool size for these amino acids was dependent upon the growth state of the algal cells. The kinetics of incorporation of radioactive amino acids from intracellular pools into protein suggested that both leucine and tyrosine occupied at least two distinct pools within the cells. Tyrosine and methionine were present in smallest amounts (38 and $37 \mathrm{amol} \mathrm{cell}^{-1}$, respectively). Leucine was present at $90 \mathrm{amol} \mathrm{cell}^{-1}$. At least 11 amino acids had higher pool concentrations than leucine, whilst only alanine and glycine were more abundant than leucine in $C$. fusca protein.

\section{INTRODUCTION}

The active uptake of phenylalanine by cells of Chlorella vulgaris and C. fusca has been investigated by Van Sumere \& Dedonder (1971) and Pedersen \& Knutsen (1974), respectively. This process exhibits saturation kinetics, with a $V_{\max }$ of $10 \mathrm{amol} \mathrm{cell}^{-1} \mathrm{~min}^{-1}$ and $K_{\mathrm{m}}$ of $5 \mu \mathrm{M}$, and is substrate-specific, although high concentrations of analogues or other amino acids cause partial inhibition of uptake. Phenylalanine is accumulated 1000 -fold inside the cells by an energy-dependent process which is abolished by preincubating low culture densities of cells with 2,4-dinitrophenol prior to addition of the amino acid. The system was found to be constitutive, operating at maximum rate immediately on amino acid addition. Uptake is a one-way process, in that no exchange occurs between intracellular phenylalanine and that in the medium, even during uptake.

In $C$. pyrenoidosa, the accumulation of proline from the medium requires intracellular glucose, although it is inhibited by large quantities of carbohydrates in the cells (McNamer \& Stewart, 1973). The process occurs chiefly in late-exponential phase cells, when the glucose in the medium of dark-grown cells is depleted.

Little is known about the accumulation of other amino acids in this organism, although there has been some work done on the uptake of other solutes, such as guanine (Pettersen \& Knutsen, 1974) and uracil (Knutsen, 1972). Maximum uptake of uracil occurs in the last $4 \mathrm{~h}$ of the light period in a synchronous culture. This is also the case for phenylalanine (Pedersen \& Knutsen, 1974). 
Active transport also occurs for sodium and potassium ions in Chlorella, as in other algae and higher plants (Barber, 1968). These transport processes appear to be ATP driven, since they are susceptible to inhibition by compounds such as 2,4-dinitrophenol and carbonyl cyanide $m$-chlorophenylhydrazone (Jeschke, 1972), and are light-dependent (Rybova et al., 1972).

Komor \& Tanner (1974) investigated hexose uptake by $C$. vulgaris using the glucose analogues 2-deoxyglucose and 6-deoxyglucose. Transport of these sugars was stoicheiometrically linked to metabolic energy (Komor et al., 1972) and took place against a concentration gradient. Their studies with the tranphosphorylation inhibitors $N, N^{\prime}$-dicyclohexylcarbodiimide, azide and oligomycin led them to conclude that uptake is driven by a high-energy intermediate prior to ATP, and that the process cannot be entirely explained in terms of the electron transport hypothesis. The sugar appeared chemically unaltered inside the cell, and was later phosphorylated by an ATP-dependent mechanism. Transport of hexose in C. vulgaris thus differs from the phosphoenolpyruvate-energized type of sugar uptake seen in Escherichia coli (Kornberg \& Jones-Mortimer, 1977).

The present study of the uptake of leucine and tyrosine by C. fusca was undertaken to investigate the suitability of these amino acids as markers for labelling proteins to measure intracellular protein turnover. Suitability for such studies depends upon rapid accumulation of such compounds from the external medium, and incorporation into protein. It is also important that an exchange equilibrium exists in both directions with the medium if an external 'trap' of unlabelled amino acid is used to avoid the problem of isotope re-incorporation.

\section{METHODS}

Culture of organism. Chlorella fusca var. vacuolata (Culture Collection of Algae and Protozoa, Cambridge, strain no. 211-8P) was grown autotrophically in a medium containing (per litre distilled water): $7.76 \mathrm{~g}$ $\mathrm{KH}_{2} \mathrm{PO}_{4}, 2.32 \mathrm{~g} \mathrm{~K}_{2} \mathrm{HPO}_{4}, 0.75 \mathrm{~g} \mathrm{NH}_{4} \mathrm{NO}_{3}, 0.4 \mathrm{~g} \mathrm{MgSO}_{4} .7 \mathrm{H}_{2} \mathrm{O}, 5 \mathrm{mg}$ iron as an $\mathrm{Fe}^{3+}$-EDTA complex, and $1 \mathrm{ml} \mathrm{A5}$ trace element solution (Arnon, 1938). The $\mathrm{pH}$ of the medium was $6 \cdot 1$, and $200 \mathrm{ml}$ volumes were aerated with sterile air containing $0.5 \%(\mathrm{v} / \mathrm{v}) \mathrm{CO}_{2}$ at $200 \mathrm{ml} \mathrm{min}^{-1}$. Cultures were grown at $25{ }^{\circ} \mathrm{C}$, and illuminated by four $60 \mathrm{~cm}, 40 \mathrm{~W}$ 'warm-white' fluorescent tubes, on two sides at a mean distance of $15 \mathrm{~cm}$ from the surface of each culture vessel, giving a mean light intensity at the surface of the culture vessel of $3.7 \times 10^{3} \mathrm{~lx}$. Under these conditions, growth of the alga was exponential until the cell density reached $2 \times 10^{7}$ cells $\mathrm{ml}^{-1}$, after which growth was light-limited, cell density increasing linearly to about $6 \times 10^{7}$ cells $\mathrm{ml}^{-1}$.

For each experiment, $100 \mathrm{ml}$ cultures were adjusted to $5 \cdot 5 \times 10^{6}$ cells $\mathrm{ml}^{-1}$ and incubated under the conditions described above for $1.5 \mathrm{~h}$ prior to the start of the experiment (usually the addition of a radioactive amino acid).

Cell number was determined using a Coulter counter model $Z_{\mathrm{BI}}$ (Coulter Electronics, Dunstable, Beds.).

Nitrogen starvation was achieved by resuspending washed cell suspensions in medium from which $\mathrm{NH}_{4} \mathrm{NO}_{3}$ had been omitted.

Measurement of uptake of radioactive amino acids. $\mathrm{L}-\left[\mathrm{U}-{ }^{14} \mathrm{C}\right]$ Leucine or $\mathrm{L}-\left[\mathrm{U}-{ }^{14} \mathrm{C}\right] \mathrm{tyrosine}(2$ to $10 \mu \mathrm{Ci}$, 74 to $370 \mathrm{kBq}$ ) was added aseptically to cultures, at the specific activities indicated in Results. At intervals, $5 \mathrm{ml}$ samples were withdrawn; $3 \mathrm{ml}$ of each sample was immediately filtered through a $0.45 \mu \mathrm{m}$ pore-size membrane filter ( $2.5 \mathrm{~cm}$ diam., HAWP 02500, Millipore), and the filtrate (a) was retained. The remaining $2 \mathrm{ml}$ was rapidly mixed with $2 \mathrm{ml} 10 \%$ (w/v) trichloroacetic acid, centrifuged after standing for $1 \mathrm{~h} \mathrm{in}$ crushed ice, and the supernatant (b) was retained. At the beginning and end of each experiment, triplicate $0.1 \mathrm{ml}$ samples of unfractionated cell suspension (c) were taken for determination of the total radioactivity per unit volume of the culture. These and triplicate $0.5 \mathrm{ml}$ samples of the filtrate (a) and supernatant (b) were mixed with $8 \mathrm{ml}$ scintillation fluid [toluene/Triton X-100/2-(4'-tert-butylphenyl)-5-(4"'-biphenylyl)1,3,4-oxadiazole $(100: 50: 1, \mathrm{v} / \mathrm{v} / \mathrm{w})]$ and counted for $10 \mathrm{~min}$ periods in a scintillation counter at $8^{\circ} \mathrm{C}$. D.p.m. were calculated using the external standard channels ratio method of quench correction. The total uptake of radioactivity by cells was calculated as $(5 c-a)$, the uptake into trichloroacetic acid-insoluble material (protein) as $(5 c-2 b)$, and the uptake into the trichloroacetic acid-soluble fraction (pool) as $(2 b-a)$. All values of sample radioactivity were then normalized to d.p.m. cell ${ }^{-1}$. Radioactivity in representative samples (a) and (b) was shown to be unchanged leucine or tyrosine, as appropriate, using chromatographic separations described fully by Richards (1978). 


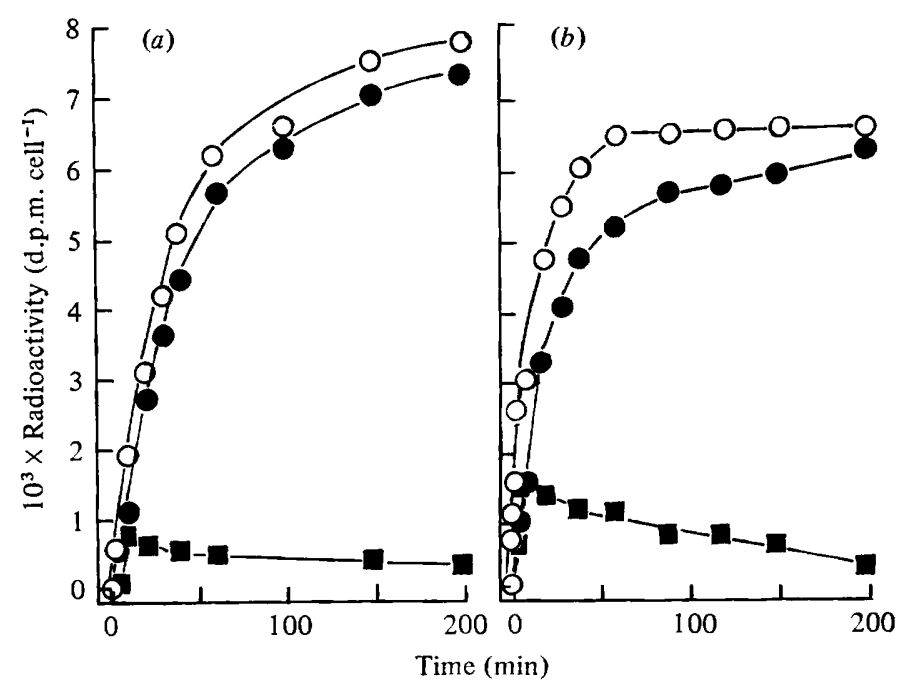

Fig. 1. Uptake of radioactive leucine (a) and tyrosine (b) by $C$. fusca. Total uptake by $C$. fusca cells $(O)$, uptake into the trichloroacetic acid-insoluble (protein) fraction $(O)$ and uptake into the trichloroacetic acid-soluble (pool) fraction $(\square)$ are shown. (a) Cells were harvested from a culture at $1.35 \times 10^{7}$ cells $\mathrm{ml}^{-1}$ and resuspended at $5 \cdot 5 \times 10^{6} \mathrm{cells} \mathrm{ml}^{-1}$. At zero time, $\mathrm{L}-\left[{ }^{14} \mathrm{C}\right] l$ leucine was added to give a concentration of $0.2 \mu \mathrm{M}$ at a specific activity of $104.8 \mathrm{Ci} \mathrm{mol}^{-1}(3.88 \mathrm{TBq}$ $\mathrm{mol}^{-1}$ ). If all of the leucine had been taken up by the cells the total uptake would have been

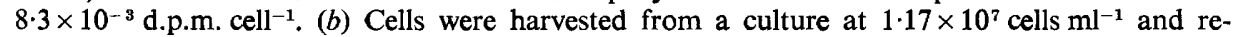
suspended at $3.5 \times 10^{6}$ cells $\mathrm{ml}^{-1}$. L-[ $\left.{ }^{14} \mathrm{C}\right]$ Tyrosine was added to give a concentration of $0 \cdot 2 \mu \mathrm{M}$ at a specific activity of $50 \mathrm{Ci} \mathrm{mol}^{-1}\left(1.85 \mathrm{TBq} \mathrm{mol}^{-1}\right)$. If all of the tyrosine had been taken up by the cells the total uptake would have been $6.85 \times 10^{-3}$ d.p.m. cell ${ }^{-1}$.

Chemical analysis of total amino acid pools. A sample of $3.75 \times 10^{10}$ cells was harvested by centrifugation from a $C$. fusca culture at a density of $1.25 \times 10^{7}$ cells $\mathrm{ml}^{-1}$. The cells was washed and resuspended in ice-cold distilled water, broken by passage twice through a French press at $135 \mathrm{MPa}$ and $4{ }^{\circ} \mathrm{C}$, made $5 \%(\mathrm{w} / \mathrm{v})$ in trichloroacetic acid and held in crushed ice for $1 \mathrm{~h}$. The supernatant recovered by centrifugation at $30000 \mathrm{~g}$ for $1 \mathrm{~h}$ at $4{ }^{\circ} \mathrm{C}$ was extracted three times with an equal volume of ether (to remove trichloroacetic acid) and then freeze-dried. The amounts of the pool amino acids were determined using an automated amino acid analyser (Locarte, London) with the buffer system described by Donald (1973). Serine, glutamine and asparagine have identical retention times in this system and so were not separated. Thus, the amount of serine plus glutamine plus asparagine in Table 2 is an approximation derived using an average value of the sensitivity of the analyser detection system for the three amino acids, determined from standard samples run separately.

Chemical analysis of cell protein. The amino acid composition of $C$. fusca protein was determined by hydrolysis in $6 \mathrm{M}$ - $\mathrm{HCl}$ followed by automated analysis for all amino acids, except glutamate, glutamine, aspartate, asparagine and tryptophan which were measured enzymically. Two fractions of cell protein, 'soluble' and 'insoluble', were analysed. Full details of the extraction of these two fractions and their analysis are described in the following paper (Richards \& Thurston, 1980). The protein composition data of Table 2 are an average for the two fractions, weighted according to their relative abundances in the cell.

Radiochemicals. These were all obtained from The Radiochemical Centre, Amersham.

\section{RESULTS}

\section{Uptake of radioactive leucine and tyrosine by $C$. fusca}

When leucine was added to a $C$. fusca culture it was rapidly assimilated. Figure 1(a) shows the incorporation of $0 \cdot 2 \mu \mathrm{M}$-leucine into whole cells and the division of the incorporated leucine between a trichloroacetic acid-soluble pool fraction and protein. The pool fraction contained only a small proportion of the total incorporated leucine except at the earliest sampling times, but retained a significant amount even when the rate of incorporation into protein approached zero. Uptake of $0.2 \mu \mathrm{M}$-tyrosine showed a similar pattern 


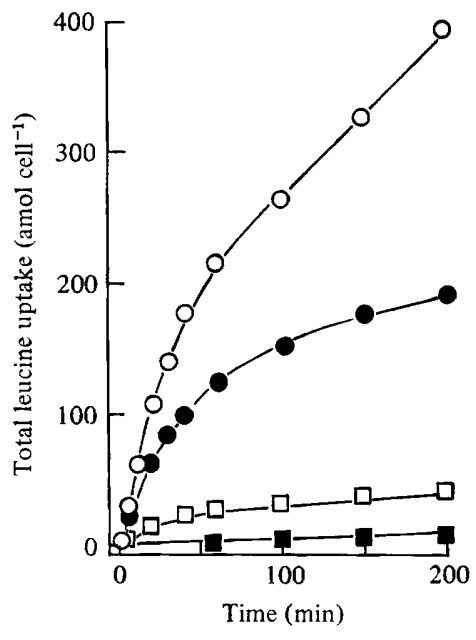

Fig. 2

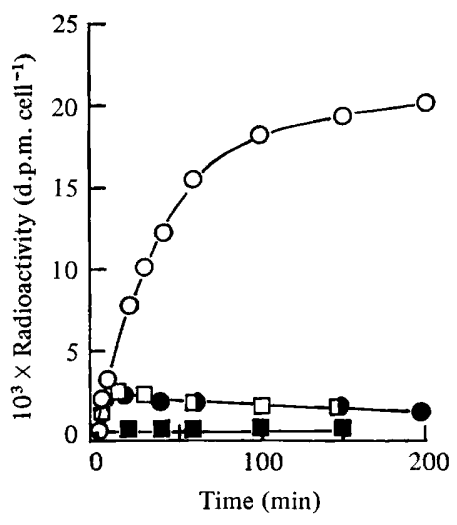

Fig. 3

Fig. 2. Effect of concentration of $\mathrm{L}_{-}\left[{ }^{14} \mathrm{C}\right]$ leucine on uptake by $C$. fusca. Total uptake of radioactive leucine by $C$. fusca suspensions containing $5.5 \times 10^{6}$ cells $\mathrm{ml}^{-1}$ is shown. The concentrations of leucine supplied at zero time were: $4 \mu_{\mathrm{M}}(\mathrm{O}) ; 1.5 \mu_{\mathrm{M}}(\Theta) ; 0.2 \mu_{\mathrm{M}}(\square) ; 0.06 \mu_{\mathrm{M}}(\square)$.

Fig. 3. Effect of 2,4-dinitrophenol on assimilation of leucine by $C$. fusca. Suspensions of $C$. fusca containing $5.5 \times 10^{6}$ cells ml-1 were supplied with $0.2 \mu \mathrm{M}-\mathrm{L}-\left[{ }^{14} \mathrm{C}\right]$ leucine. Uptake, in the absence $(\bigcirc, \square)$ and in the presence $(O, \square)$ of $0.2 \mathrm{~mm}$-2,4-dinitrophenol, into the trichloroacetic acidinsoluble fraction $(\bigcirc, \square)$ and the trichloroacetic acid-soluble (pool) fraction $(O, \square)$ is shown. Where 2,4-dinitrophenol was used, cells were preincubated for $0.5 \mathrm{~h}$ in the presence of the inhibitor before adding the radioactive amino acid.

(Fig. $1 b$ ), but a higher proportion of incorporated amino acid was initially found in the pool fraction and it was progressively assimilated into protein.

Total incorporation of leucine supplied at a range of concentrations is shown in Fig. 2. The initial rates of uptake calculated from these results were transformed as double reciprocal plots (not shown), together with comparable data for tyrosine. From these, the apparent $K_{\mathrm{m}}$ for uptake of leucine was $2.5 \mu \mathrm{M}$ and the calculated maximum rate of uptake was 10 amol cell ${ }^{-1} \mathrm{~min}^{-1}$. The corresponding values for tyrosine were $0.4 \mu \mathrm{M}$ and $6 \mathrm{amol}$ cell ${ }^{-1} \min ^{-1}$, respectively.

Uptake of $0 \cdot 2 \mu \mathrm{M}$-leucine and $0 \cdot 2 \mu \mathrm{M}$-tyrosine was not inhibited by the simultaneous addition to the medium of phenylalanine, threonine or serine at $2 \mu \mathrm{M}$ (results not shown). The effect of the uncoupling agent 2,4-dinitrophenol is shown in Fig. 3. Although incorporation of radioactive leucine into protein was completely inhibited, uptake into the pool fraction was not affected. The same result was obtained when the experiment was repeated with a $C$. fusca culture in the dark, supplied with $55 \mathrm{~mm}$-glucose as carbon and energy source. This effect was also observed with tyrosine, both in the light and in the dark with glucose supplied.

\section{Effect of growth state on apparent pool size}

Table 1 shows the amount of radioactive leucine in the pool fraction $15 \mathrm{~min}$ after adding $0 \cdot 2 \mu \mathrm{M}-\mathrm{L}-\left[{ }^{14} \mathrm{C}\right]$ leucine to suspensions of cells (adjusted to $5 \cdot 5 \times 10^{6}$ cells $\mathrm{ml}^{-1}$ ) taken from cultures which had grown to a range of cell densities. Suspensions of cells from the exponential phase of growth showed similar apparent pool sizes, but as the growth rate declined due to light limitation, the amount of leucine taken up into the pool fraction increased. 


\section{Table 1. Apparent leucine pool size of C. fusca suspensions harvested at different stages of batch culture}

Samples of $C$. fusca suspensions adjusted to $5 \cdot 5 \times 10^{6}$ cells $\mathrm{ml}^{-1}$ were supplied with $0 \cdot 2 \mu \mathrm{M}-\mathrm{L}_{-}\left[{ }^{14} \mathrm{C}\right]-$ leucine for $15 \mathrm{~min}$, and then radioactivity in the pool fraction was determined. All values of pool size are $\pm 9 \%$.

$\begin{array}{cc}\begin{array}{c}10^{-6} \times \\ \text { Culture density* } \\ \text { (cells ml }\end{array} \text { ( ) }^{*} & \begin{array}{c}\text { Leucine pool } \\ \text { (amol cell }^{-1} \text { ) }\end{array} \\ 4.4 & 0.47 \\ 19 & 0.53 \\ 25 & 0.56 \\ 40 & 1 \cdot 7 \\ 53 & 2.8\end{array}$

* Points at which samples were taken for measurement of leucine taken up.

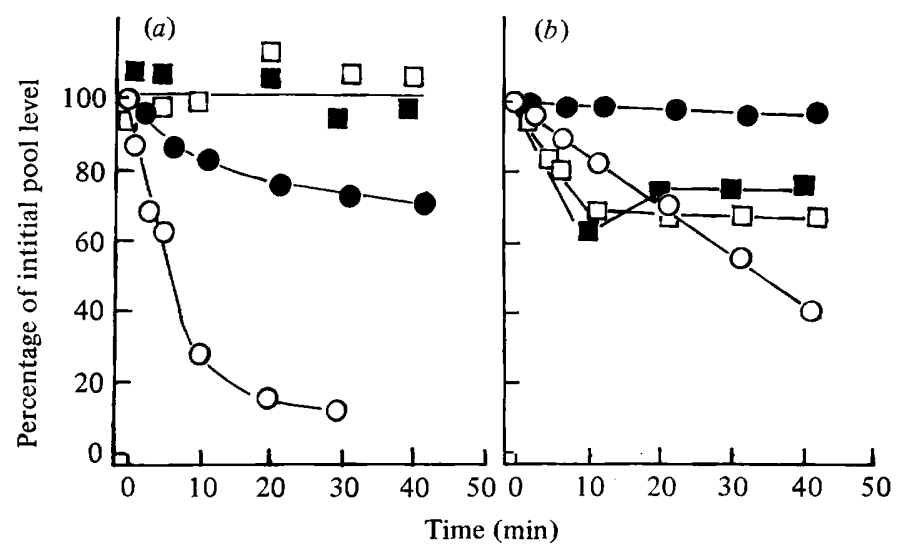

Fig. 4. Effect of cycloheximide and 'cold traps' on leucine (a) and tyrosine (b) pools in $C$. fusca. Suspensions of $C$. fusca containing $5.5 \times 10^{6}$ cells $\mathrm{ml}^{-1}$ were supplied with $0.2 \mu \mathrm{M}-\mathrm{L}-\left[{ }^{14} \mathrm{C}\right]$ leucine (a) or $0.2 \mu \mathrm{M}-\mathrm{L}-\left[{ }^{14} \mathrm{C}\right]$ tyrosine $(b)$ for $15 \mathrm{~min}$, and then the cells were harvested, washed and resuspended in fresh medium ( $\bigcirc$ ), medium containing $2.5 \mu \mathrm{g}$ cycloheximide $\mathrm{ml}^{-1}(\bigcirc)$, medium containing $1 \mathrm{~mm}$ unlabelled leucine or tyrosine as appropriate $(\square)$, or medium containing both $2.5 \mu \mathrm{g}$ cycloheximide $\mathrm{ml}^{-1}$ and $1 \mathrm{~mm}$ unlabelled amino acid ( $\square$ ). Radioactive amino acid in the pool fractions was determined as described in Methods.

\section{Exchange of leucine and tyrosine in the pool fraction with unlabelled amino acids added to the medium}

The leucine pool of an exponentially growing $C$. fusca suspension was loaded with radioactive leucine, and then the cells were washed and resuspended in medium containing $1 \mathrm{~mm}$ unlabelled leucine (Fig. 4a). Radioactivity in the pool remained constant for $50 \mathrm{~min}$ with no measurable incorporation of radioactivity into protein or exchange of radioactive leucine with the unlabelled 'trap' in the medium. In the absence of the trap, pool radioactivity declined as more than $80 \%$ of the leucine radioactivity was incorporated into protein, and this incorporation was reduced to $20 \%$ when cycloheximide was present (Fig. $4 a$ ). This experiment was repeated with a light-limited $C$. fusca suspension where five times more leucine radioactivity was present in the pool fraction (see Table 1). Again, more than $80 \%$ of the radioactive leucine was incorporated into protein within $50 \mathrm{~min}$ in the absence of unlabelled leucine or cycloheximide, but no exchange into the medium was detected in the presence or in the absence of the trap or cycloheximide.

The behaviour of the tyrosine pool fraction in similar experiments is shown in Fig. 4(b). When a cold trap was added the pool radioactivity was initially reduced by about $30 \%$ both 


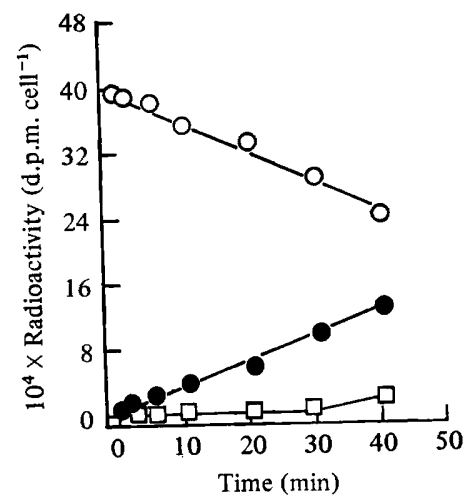

Fig. 5. Efflux from the leucine pool in nitrogen-starved $C$. fusca. Cells were washed and resuspended in nitrogen-free medium at $5 \times 10^{6}$ cells ml ${ }^{-1}$ for $2 \mathrm{~h}$, and then $0 \cdot 2 \mu \mathrm{M}-\mathrm{L}-\left[{ }^{14} \mathrm{C}\right]$ leucine $\left(50 \mathrm{Ci} \mathrm{mol}^{-1}\right.$, $1.85 \mathrm{TBq} \mathrm{mol}^{-1}$ ) was added. After $20 \mathrm{~min}$ the cells were harvested, resuspended in nitrogen-free medium containing $1 \mathrm{mM}$ unlabelled L-leucine and sampled for radioactivity in the pool fraction $(\bigcirc)$, in the culture medium $(\bullet)$ and in cell protein $(\square)$, as described in Methods.

\section{Table 2. Amino acid composition of C. fusca protein and intracellular pool fractions} determined by automated analysis

The amino acid content of the trichloroacetic acid-soluble (pool) and the trichloroacetic acidinsoluble (protein) fractions was determined as described in Methods. Values for protein are the mean of three experiments on separate cultures, and pool values are the mean of nine determinations made on cells from two cultures.

Pool fraction

\begin{tabular}{|c|c|c|c|}
\hline Amino acid & amol cell ${ }^{-1}$ & $\%$ total pool & $\begin{array}{l}\text { Standard } \\
\text { error }\end{array}$ \\
\hline Aspartate & 492 & 6.89 & 0.18 \\
\hline Threonine & 201 & $2 \cdot 82$ & $0 \cdot 31$ \\
\hline Serine & & & \\
\hline $\left.\begin{array}{l}\text { Asparagine } \\
\text { Glutamine }\end{array}\right\}$ & 798 & $11 \cdot 18$ & 0.17 \\
\hline Glutamate & 1794 & $25 \cdot 15$ & 0.07 \\
\hline Proline & 1352 & 18.95 & 0.60 \\
\hline Glycine & 219 & 3.08 & 0.20 \\
\hline Alanine & 827 & $11 \cdot 59$ & 0.10 \\
\hline Cysteine & 131 & 1.83 & 1.81 \\
\hline Valine & 125 & $1 \cdot 75$ & $0 \cdot 22$ \\
\hline Methionine & 37 & 0.51 & 0.82 \\
\hline Isoleucine & 55 & 0.77 & 0.38 \\
\hline Leucine & 90 & $1 \cdot 26$ & 0.34 \\
\hline Tyrosine & 38 & 0.53 & 0.45 \\
\hline Phenylalanine & 60 & 0.85 & $0 \cdot 32$ \\
\hline Histidine & 42 & 0.59 & 0.26 \\
\hline Tryptophan & 234 & $3 \cdot 28$ & 0.36 \\
\hline Lysine & 117 & 1.65 & 0.22 \\
\hline Arginine & 521 & $7 \cdot 31$ & $0 \cdot 15$ \\
\hline
\end{tabular}

Protein fraction

\begin{tabular}{cc}
\hline & $\begin{array}{c}\text { Standard } \\
\text { error } \%\end{array}$ \\
3.21 & 0.08 \\
5.17 & 0.08 \\
6.47 & 0.04 \\
5.17 & 0.08 \\
7.73 & 0.10 \\
1.91 & 0.01 \\
6.96 & 0.03 \\
8.89 & 0.08 \\
10.23 & 0.04 \\
3.12 & 0.11 \\
6.98 & 0.02 \\
1.24 & 0.66 \\
4.23 & 0.06 \\
8.84 & 0.09 \\
2.57 & 0.03 \\
4.01 & 0.19 \\
1.91 & 0.11 \\
0.38 & 0.01 \\
6.21 & 0.13 \\
4.68 & 0.04
\end{tabular}

in the presence and in the absence of cycloheximide, but the residual two-thirds of the pool radioactivity did not exchange into the medium nor was it incorporated into the protein fraction.

\section{Effect of nitrogen starvation}

The uptake and incorporation of $0 \cdot 2 \mu \mathrm{M}$-leucine and $0 \cdot 2 \mu \mathrm{M}$-tyrosine by cells which had been nitrogen-starved for $2 \mathrm{~h}$ were the same as shown above for growing cells. When $0 \cdot 2 \mu \mathrm{M}$-leucine was added for $20 \mathrm{~min}$ to cultures after $2 \mathrm{~h}$ of nitrogen starvation and the cultures were then washed and resuspended in fresh nitrogen-free medium containing an 
Table 3. Uptake of $0 \cdot 2 \mu \mathrm{M}$-leucine and $0 \cdot 2 \mu \mathrm{M}$-tyrosine into intracellular pools of C. fusca

$\begin{array}{lcc} & \text { Leucine } & \text { Tyrosine } \\ \text { Available internal volume* } & 100 \mathrm{~m}^{3} \mathrm{cell}^{-1} & 100 \mu \mathrm{m}^{3} \mathrm{cell}^{-1} \\ \text { Amount of exogenous amino acid entering pool fraction } & & \\ \text { in an uptake experiment (after 10 min incorporation) } & 3.395 \mathrm{amol} \mathrm{cell}^{-1} & 13 \cdot 87 \mathrm{amol} \mathrm{cell}^{-1} \\ \text { Internal amino acid concn } & 33.95 \mu \mathrm{M} & 138 \cdot 7 \mu \mathrm{M} \\ \text { Residual amino acid concn outside cell } & 0.153 \mu \mathrm{M} & 0 \cdot 151 \mu \mathrm{M} \\ \text { Concentration factor } & 222 \times & 920 \times\end{array}$

* This value is based on Coulter counter measurements of mean cell volume, and assumes the whole volume of the cell is available to the internal pool. If this assumption is not true (for example, if the pool is located in a specific compartment such as the vacuole) the available volume will be less, and the concentration factor will be correspondingly greater than that calculated here.

external trap and cycloheximide, the pool radioactivity was progressively lost to the medium (Fig. 5).

\section{Chemical estimation of amino acid pools in C. fusca}

Amino acids in the trichloroacetic acid-soluble fraction of $C$. fusca cells taken from an exponentially growing culture are shown in Table 2, both as absolute amounts per cell and as percentages of the total amino acid pool, in order to allow comparison with their relative abundance in total C. fusca protein. The amount of proline shown in the pool fraction may be an overestimate as this amino acid was eluted next to glutamate which is present in relatively large amounts. The amounts of both leucine and tyrosine found in the pool fraction are 10 to 20 times greater than the amounts of radioactive amino acid taken up from the medium into this pool fraction by exponentially growing cells, where the initial extracellular concentration of amino acid was $0 \cdot 2 \mu \mathrm{M}$.

\section{DISCUSSION}

Both leucine and tyrosine were taken up by $C$. fusca cells via high affinity uptake mechanisms which were not general amino acid permeases as uptake was not inhibited by a 10fold higher initial concentration of phenylalanine, threonine or serine. The amino acids were both taken up to give a final pool concentration very much greater than the residual concentration in the medium. When $0.2 \mu \mathrm{M}$-leucine was supplied to growing cells the concentration in the pool fraction was 222 times greater than in the medium after $10 \mathrm{~min}$ of incorporation (Table 3) if the calculation was based only on the radioactive leucine supplied. The chemical determination of free leucine in $C$. fusca cells (Table 2) suggested that this was a considerable underestimate.

Under the same conditions tyrosine was concentrated 920 times inside the cells (again taking no account of the extra endogenously synthesized free tyrosine). The exact concentrations of free leucine and tyrosine in the pool fraction during uptake experiments were not determined and could not be calculated from these results as it was not determined whether amino acid taken up from the medium expanded an existing pool or replaced endogenously synthesized amino acid, thus conserving a constant pool size.

In the same way the increase in the amount of radioactive leucine found in the pool fraction as growth rate declined (Table 1) could be due to an absolute increase in pool size and/or to replacement of a decreased proportion of the pool by endogenously synthesized leucine.

Both amino acids were, nevertheless, taken up against a substantial concentration gradient by an energy-requiring process. We are consequently unable to explain why the uncoupling agent 2,4-dinitrophenol did not inhibit uptake. This inhibitor was expected to prevent ATP 
synthesis by the processes of photophosphorylation and oxidative phosphorylation leaving substrate level phosphorylation as the sole source of ATP. Syrett (1958) has shown a marked drop in ATP levels when nitrogen-starved $C$. fusca cells were given $0.2 \mathrm{~mm}$-2,4-dinitrophenol. As protein synthesis was completely stopped by the inhibitor, we conclude that either uptake uses energy which is not acquired via ATP, or the ATP requirement can be satisfied by very low ATP levels which are insufficient for protein synthesis.

The intracellular pools of leucine and tyrosine did not readily exchange with the same amino acid added to the medium as a 'trap'. With growing cells leucine did not exchange out of the cells to a measurable extent, and when the cells were nitrogen-starved exchange was slow with a half-time of about $1 \mathrm{~h}$. About $30 \%$ of the tyrosine pool of growing $C$. fusca cells exchanged relatively quickly with tyrosine added to the medium, but the residual $70 \%$ did not.

These results suggest that the pool fraction detected here is composed of several metabolically distinct pools. When the leucine pool fraction was loaded with radioactive amino acid and then a high exogenous concentration of unlabelled amino acid was supplied, the pool radioactivity was conserved (Fig. $4 a$ ), so that within the limits of these measurements all of the radioactivity was in a pool which was not consumed by protein synthesis, nor was it able to exchange with the leucine in the medium. When no trap was supplied but cycloheximide was added, about a third of the labelled leucine of the pool was incorporated into protein. If this labelling was due to organellar protein synthesis (which would not be expected to be inhibited by the antibiotic), it is noteworthy that no such comparable incorporation was observed with tyrosine. Although the present results are insufficient to formulate a detailed kinetic model, they are consistent with the presence in C. fusca of storage pools of amino acids which are not always in rapid equilibrium with the precursor pools for protein synthesis nor with amino acids being taken up from the medium. The existence of storage pools has been suggested for a number of other eukaryotic organisms, for example Neurospora (Zalokar, 1961), maize (Oaks, 1965) and mammals (Mortimore et al., 1972; Kipnis et al., 1961). In C. fusca it has been demonstrated that there are at least two pools of amino acids, one of which is rapidly labelled with ${ }^{14} \mathrm{C}$ during photosynthesis with labelled carbon dioxide; this pool represents only 20 to $50 \%$ of the total pool for several amino acids (Smith et al., 1961).

In conclusion, the leucine and tyrosine pool fractions in $C$. fusca are complex and in growing cells these amino acids do not readily exchange from the pool fraction into the medium. Trapping of radioactive amino acids released from prelabelled protein is therefore not a suitable method for measuring overall rates of protein degradation (turnover) in this organism. The results of Halvorson $(1958 a, b)$ for Saccharomyces cerevisiae and of Davies \& Humphrey (1978) for Lemna minor and Schizosaccharomyces pombe suggest that this restriction is common in eukaryotic organisms.

We wish to thank the Science Research Council for a studentship to one of us (L.R.)

\section{REFERENCES}

ARNon, D. I. (1938). Microelements in culture solution experiments with higher plants. American Journal of Botany 25, 322-325.

BARBer, J. (1968). Measurement of the membrane potential and evidence for active transport of ions in Chlorella pyrenoidosa. Biochimica et biophysica acta 150, 618-625.

Davies, D. D. \& Humphrey, T. J. (1978). Amino acid recycling in relation to protein turnover. Plant Physiology 61, 54-58.

Donald, A. S. R. (1973). The products of pronase digestion of purified blood group specific glycoproteins. Biochimica et biophysica acta 317, 420. 436.

Halvorson, H. O. (1958a). Intracellular protein and nucleic acid turnover in resting yeast cells. Biochimica et biophysica acta 27, 255-266.

Halvorson, H. O. (1958b). Studies on protein and nucleic acid turnover in growing cultures of yeast. Biochimica et biophysica acta 27, 267-276.

JESCHKE, W. D. (1972). The effect of DNP and CCCP on photosynthesis and light-dependent $\mathrm{Cl}^{-}$ 
influx in Elodea densa. Zeitschrift für Pflanzenphysiologie 66, 409-419.

Kipnis, D. M., Reiss, E. \& Helmreich, E. (1961). Functional heterogeneity of the intracellular amino acid pool in mammalian cells. Biochimica et biophysica acta 51, 519-524.

KNUTSEN, G. (1972). Uptake of uracil by synchronous cultures of Chlorella fusca. Physiologia plantarum 27, 300-309.

Komor, E. \& TANNER, W. (1974). The nature of the energy metabolite responsible for sugar accumulation in Chlorella vulgaris. Zeitschrift für Pflanzenphysiologie 71, 115-128.

Komor, E., HaAss, D. \& TANner, W. (1972). Unusual features of the active hexose uptake system of Chlorella vulgaris. Biochimica et biophysica acta 266, 649-660.

KornberG, H. L. \& Jones-Mortimer, M. C. (1977). The phosphotransferase system as a site of cellular control. Symposia of the Society for General Microbiology 27, 217-240.

MCNamer, A. D. \& Stewart, C. R. (1973). Proline uptake and utilisation by Chlorella pyrenoidosa. Plant Physiology 52, 561-564.

Mortimore, G. E., Woodside, K. H. \& Henry, J. E. (1972). Compartmentation of free valine and its relation to protein turnover in perfused rat liver. Journal of Biological Chemistry 27, 27762784.

OAKs, A. (1965). The soluble leucine pool in maize root tips. Plant Physiology 40, 142-149.

Pedersen, A. G. \& Knutsen, G. (1974). Uptake of L-phenylalanine in synchronous Chlorella fusca. Characterization of the uptake system. Physiologia plantarum 32, 294-300.
Pettersen, R. \& Knutsen, G. (1974). Uptake of guanine by synchronised Chlorella fusca. Characterization of the transport system in autospores. Archives of Microbiology 96, 233-246.

RICHARDS, L. (1978). Measurement of intracellular protein turnover in the green alga Chlorella. Ph.D. thesis, University of London.

Richards, L. \& Thurston, C. F. (1980). Protein turnover in Chlorella fusca var. vacuolata: measurement of the overall rate of intracellular protein degradation using isotope exchange with water. Journal of General Microbiology 121, 49-61.

Rybova, R., Janacek, K. \& Slavikova, M. (1972). Ionic relations of the alga Hydrodictyon reticulatum. The effects of light conditions and inhibitors. Zeitschrift für Pflanzenphysiologie 66 , $420-432$.

Smith, D. C., Bassham, J. A. \& KIRK, M. (1961). Dynamics of the photosynthesis of carbon compounds. II. Amino acid synthesis. Biochimica et biophysica acta 48, 299-313.

SyretT, P. J. (1958). Respiration rate and internal ATP concentration in Chlorella. Archives of Biochemistry and Biophysics 75, 117-124.

Van Sumere, C. F. \& Dedonder, A. (1971). The effect of some naturally occurring and synthetic phenolics and related compounds on the uptake and incorporation of phenylalanine-1-( $\left.{ }^{14} \mathrm{C}\right)$ by Chlorella vulgaris. Zeitschrift für Pflanzenphysiologie 65, 159-175.

ZALOKAR, M. (1961). Kinetics of amino acid uptake and protein synthesis in Neurospora. Biochimica et biophysica acta 46, 423-432. 